\title{
Medical Students Dynamic Effort on Understanding of RNAi Therapeutic Application in Sri Lanka
}

\author{
Faiz MMT Marikar \\ Staff Development Centre, General Sir John Kotelawela Defence University, Rathmalana, 10390, Sri Lanka \\ Email: faiz.marikar@fulbrightmail.org
}

\begin{abstract}
Manel BCN Kulugammana, Karawitage RL Karawita, Aravinda S Jayathilake, Ayesh U Hettiarachchi, Kesaven Kalainesan, Eranda I Kumara, Kodithuwakkulage MP Kumara Faculty of Medicine, University of Rajarata, Saliyapura, Anuradapura, 56000, Sri Lanka
\end{abstract}

Email: \{kulagammana78, karawita2, jayathilake2000, hettirjt, kalainesan76, kumaraei, kumarakodi\}@ gmail.com

\begin{abstract}
This study examines students' understanding of the normative connections between key concepts of genetics, and RNAi and underlying biological principles that are critical for an in-depth understanding of RNAi therapeutic application on Medical field. Using a structural questionnaire, we examine randomly selected Medical faculty students' understanding of genetic relationships at Faculty of Medicine and Allied Sciences, University of Rajarata, Sri Lanka. A total of 80 Medical faculty students participated in this study and completed written questionnaire on genetics and RNAi therapeutic application. Findings from this study were there is a strong positive response on basic genetics studies in this content, but when it considers knowledge on RNAi and new technology based on RNAi therapeutic application is poorly understood. Almost all the students had a good knowledge on DNA but not the relationship between gene and DNA. Specifically, students were requested to demonstrate an integrated understanding of the RNAi therapeutic application, almost $96 \%$ of them unable to give an example for it, and also some students struggled to explain it. Outcome of this study is preliminary in nature; the results provide a glimpse of genetics education in Sri Lanka need to uplift.
\end{abstract}

Index Terms-Genetics, genetics education, RNAi, therapeutic application.

\section{INTRODUCTION}

In this digital age many people used to say that we must get rid of biotechnological age which was used to be earlier. Digitalized people have the mistaken notion that every person can learn to live in this new age with a minimum of effort and understanding of genetic which is not correct in my way thinking $(1,2)$. The terms "genetics" and "gene" name was evolved a centaury ago, but the understanding of the genetics about function of the cell was evolved 1950s (3).

In school curriculum Science and Genetics are two most extremely difficult subjects in the biology students in Sri Lankan $(4,5)$ and furthermore it is still difficult at college and university levels $(6,7)$. Understanding of genetics studies revealed that genetics and its various aspects is poor among students of various part of the world (8-10). In this current era recent and past Genetics education has become increasingly important with the advent of recombinant DNA technologies, and RNA interference technologies and the subsequent emergence and availability of its benefits for the patients (11).

RNAi is a regulatory mechanism of most eukaryotic cells that uses small double stranded RNA (dsRNA) molecules to direct homology-dependent control of gene activity(12). Several rapidly and newly developing Ribose Nucleic Acid interference methodologies hold the selectively inhibit the gene expression in mammals. Application of RNAi technology is currently being used not only as an extremely powerful instrument for functional genomics analyses, but it can be used as a potentially useful method to develop highly specific dsRNA based gene-silencing therapeutics.

Implications of recent developments of the so-called "New Genetics" have been widely discussed in the scientific community and among the general public. Legal and ethical concerns focus on policy agenda: the appropriate use of genetic tests and population screening, the possibility of genetic discrimination, and the "destiny" of transgenic resources (13-15). Research on the public understanding of genetics has shown that Mendelian concepts are not always understood, and lay ideas are used to explain heredity phenomena in different settings $(16,17)$.

To the best of my knowledge regarding RNAi studies almost there is no reports in Sri Lanka which have examined students' knowledge and understanding of biology topics related to genetics. In this study, we addressed the questionnaire although it is new to our students, I have addressed this area of science education research in a nutshell, which has relevance for curriculum developers, textbook writers, and teachers to think and teach new technologies in this beautiful country Sri 
Lanka $(18,19)$.

\section{METHOdOLOGY OF RESEARCH}

\section{General Background of Research}

This research was designed to collect knowledge on RNAi and its therapeutic applications ideas on inheritance of genetic disorders. The questionnaire which was administrated to the medical students had three parts: Student responses in the Gene section, Student responses in the RNAi section, and Student responses in the RNAi therapeutic application, and detail follows

\section{Mapping student knowledge on genetic code}

In Figure 1, represent that illustrates the biological relationships between DNA, RNA and Gene which will finally produce a protein. Actually we were trying to identify whether they know about the central dogma. It shows that genes and chromosomes are contained in all cells, and it was made up with nucleotides. The representation also illustrates key biological distinctions in the processes of protein production. Furthermore, this biological representation serves as a starting point for our research into the ideas and connections among ideas that students hold about basic genetics.
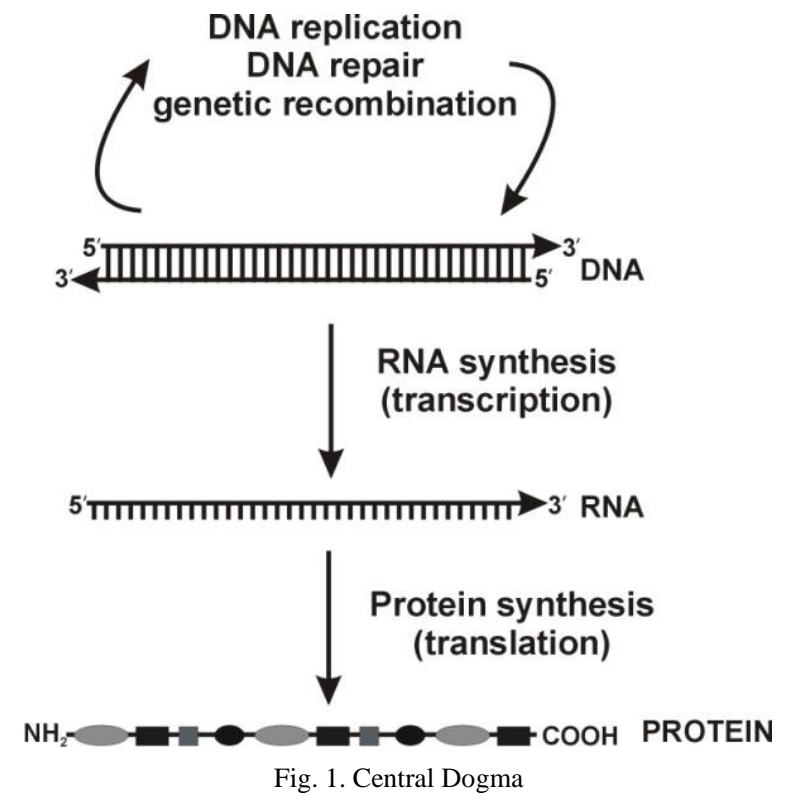

\section{Students' ideas on some basic aspects related to $R N A i$}

The main aim of this section is to show what students knew about the basic scientific concepts related to the RNAi: (a) before their first academic approach to genetics; and (b) after they had studied these basic notions in a traditional way (i.e., by teacher explanation and textbooks).

RNAi considered as double stranded RNA (dsRNA) caused potent and sequence specific silencing of homologous genes. Beyond this, the response to dsRNA had a number of nearly unbelievable properties. Silencing occurred not only in cells directly exposed to the dsRNA, but also spread throughout the organism and into its progeny. In this section, the study of RNAi has proceeded along two parallel tracks. The first is an effort to understand the biology of this response - its mechanism and its role in the organism. The second has been the desire to develop RNAi as an experimental possibly therapeutic tool which is used in this decade (Fig 2).

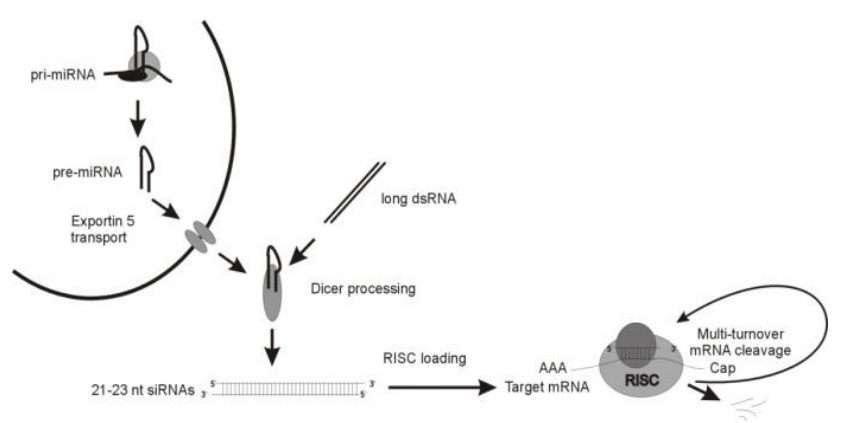

Fig. 2. Pathway and formation of RNAi

From the point of view of the logic of the discipline, and as a first approach to genetics, an elementary knowledge of the location of biological inheritance information in people, organisms in whose life cycle the diploid state is dominant. To understanding of the concepts of genetics following questions were asked (Fig. 2):

a) Ribose Nucleic Acid interference stands for WOF?

b) Nobel Prize was won by Andrew Fire and Craig Mello in 2006 for their work, begun in the late 1990s, on RNAi. WOF organisms did they work on?

c) The short double-stranded RNA which effectors of gene silencing molecules produced by the action of the enzyme dicer. Approximately what is the size of the molecules?

d) There is a application on RNAi which will have a wide range of medical therapeutical applications. It may be possible to use micro RNAs to malfunction of the oncogenes. WOF is caused by oncogenes?

e) Why can transgenes activate RNAi (can circle more than one)

\section{Student responses in the RNAi therapeutic application}

Although the technology of RNAi and initial procedures involved in therapeutic in human application, the end-products and applications are different. In therapeutic RNAi, a cloned plasmid is created and stimulated so that it begins growing. (Just like reproductive cloning, this involves inserting the genetic material of a donor into target region so that the resulting is cure to the patient.). In this sectional study also wanted to know what students knew about how some RNAi therapy in real time. For this, questions asked them whether they know any examples with regard to RNAi therapeutic application. 
a) Patients who have a disease called $X$ have over growth in muscle. Scientists know that $X$ is inherited (caused by a gene). Therefore, the gene responsible for $\mathrm{X}$ does not contain correct information about

b) To cure the above symptoms RNAi therapy can be introduce, what is the main function of it.

c) Give an example of an RNAi therapy which is used current treatment to cure any disease/s

Educational researchers, on the other hand, have stressed student's "misunderstanding" of scientific concepts of genetics taught at school, such as genes, chromosome, DNA, and RNAi (10). The findings showed that students do not have a good understanding of RNAi and do not make the link between related concepts of their own with respect to RNAi therapeutic application Learning failure is seen either as a result of inadequate teaching of concepts or because the students are simultaneously exposed to a wide variety of concepts and processes at different levels of complexity.. However, all these investigations were aimed at describing the failure of the teaching-learning process rather than at understanding what students actually

\section{Sample selection}

In this study it was examined knowledge and understanding of basic genetics and Ribose Nucleic Acid interference application in therapeutic application among medical faculty students in the University of Rajarata, Sri Lanka. This topic was judged to be the best tool for extremely important for measure the good conceptual understanding of genetics and to find out in detail knowledge on current trend in Ribose Nucleic Acid interference technology.

\section{Instrument and procedure Questionnaire Used}

A written questionnaire, developed by our team at University of Rajarata as part of the "Learning in genetics with Ribose Nucleic Acid interference therapeutic application," The questionnaire itself has three parts: the "Gene" section; "Ribose Nucleic Acid interference" section; and the "Ribose Nucleic Acid interference application" section. It combines both fixedand free answer-type questions which made user friendly manner. The questionnaire was used in the Sri Lanka for medical faculty students first time. Use of the questionnaire in this study was justified because it had been prepared by an experienced research group working in genetics education in the faculty and the county as a whole and already had been tested before the research part and optimized it. Furthermore, the questionnaire was designed to assess basic understanding of genetics also included in Sri Lankan university curriculum.

\section{Research Context and Participants}

In this study four batches were represented equally from, freshers, sophomores, juniors and seniors from Faculty of Medicine and Allied Sciences, University of Rajarata, Sri Lanka, which was located in Saliyapura,
Anuradhapura, Sri Lanka. All students were enrolled in medical education course. This study was conducted with a sample of 80 students (46 males and 34 females). Except the fresher's the rest of the students learned about basic of genetics, and gene knockdown, and molecular genetics. This medical faculty is a socially and economically diverse community in Northern Province of the country which represent all three communities well. The participating medical school was the only medical faculty in that province. These students had the biochemistry backgrounds and appeared in the selection examination (an examination conducted by the faculty for $2^{\text {nd }}$ MBBS) after completing their 2-yr courses to qualify for the final examination conducted by the Faculty.

\section{Administration of Questionnaire to the Medical Students}

The Medical Faculty students at University of Rajarata subjected to the sample and questionnaires were administered at each of the respective batches. Questionnaire was given within the class periods of 50 min with the help of the lecture in charge. Randomly selected students of 20 in number were given the questionnaires from each batch.

\section{Data Analysis}

The validity of the translation was independently assessed by two observers competent in English language. Data was analyzed as a balanced Figure as percentage of application because there is no requirement for advance analysis. Statistical analysis was done via transformed all the data using the basic statistical analysis package.

\section{Results}

\section{Gene Section}

A basic description of the section 1 known as gene section of the questionnaire is available in Table 1 . In summary, the questions examined knowledge and understanding of the genetics and its relationship was examined in this section. More attention was given to estimating students' awareness of the concept that "DNA and its importance". First three questions of this study reported here, students were tested their knowledge on whether they can identify a gene, and how it was made, as given below.

a Which phrase best describes what genes are like?

b What, if any, is the connection between DNA and genes? There were multiple answers in this scetion

c DNA and RNA are made of what?

Student responses to these three questions in this study are summarized in Table 1. It was found that only $7.5 \%$ of the total number of students positively responded all the questions. Most of the $3^{\text {rd }}$ year students were the 
Table 1. Student responses in the gene section

\begin{tabular}{|l|l|l|}
\hline $\begin{array}{l}\text { Question (Science } \\
\text { concept) }\end{array}$ & Possible responses & $\begin{array}{l}\text { \% of students } \\
\text { giving response } \\
(\mathrm{n}=80)\end{array}$ \\
\hline $\begin{array}{l}\text { Which analogy best } \\
\text { describes } \\
\text { what genes are like }\end{array}$ & $\begin{array}{l}\text { Genes are like } \\
\text { commanders } \\
\text { that control our traits }\end{array}$ & 61.3 \\
\hline $\begin{array}{l}\text { What, if any, is the } \\
\text { connection between } \\
\text { DNA and genes? } \\
\text { (can circle more } \\
\text { than one answer) }\end{array}$ & $\begin{array}{l}\text { Genes are segments of } \\
\text { DNA }\end{array}$ & $\begin{array}{l}\text { Genes determine our } \\
\text { traits and } \\
\text { DNA make us up }\end{array}$ \\
\hline $\begin{array}{l}\text { DNA and RNA are } \\
\text { made of }\end{array}$ & Nucleotides & 91.3 \\
\hline
\end{tabular}

given the correct answer on this section when compared the whole data set. Regarding the gene it was $61.3 \%$ which is slightly above average and satisfactory, but not significant. Basic question which was refereed in this section was DNA and RNA how they made up, I was expecting $100 \%$, but the outcome of the research is $91.3 \%$, which made me to think how to teach the basics to students.

Student answered to this question in this section pointed toward two miss matched concepts-the relationship among gene and DNA and surprisingly what is gene. Using the two concepts, students' "understanding", can be described as falling within one of the following categories:

- understands the basic idea of DNA and RNA is overall satisfactory

- $\quad$ understands the basic idea about gene but does not distinguish between relationship with DNA

- poor understanding it gives confused or incorrect responses. So, none of the students gave the correct answer for all three questions on this section

\section{RNAi section}

In this RNAi section in the questionnaire students were asked to self evaluate or test the knowledge on RNAi In this questionnaire section had three questions. Question 1 was what it stands for Ribose Nuclear Acid interference and surprising slightly more than $50 \%$ given the correct answer (Table 2). Being in medical field and not knowing Ribose Nuclear Acid interference is nothing to surprise. Student responses to each question are given in Table 2. To find out general knowledge among medical faculty students, I have given this question. Andrew Fire and Craig Mello regarding to check the history but students not aware, extremely sad to say the outcome was only $16.3 \%$. By looking at the results what I felt is university students must grab knowledge by active learning which is lack at the movement. Wrong explanations was given in question number three mainly to the following misconceptions, The short double stranded RNA which effectors of gene silencing molecules produced by the action of the enzyme dicer. Approximately what is the size of the molecules? In realistic situation regarding the size of the RNAi was known by only $10 \%$. The students had widespread misconceptions, such as: "No Idea" (student 40 out of 80) in this particular question.

\section{RNAi therapeutic application section}

In this RNAi therapeutic application section, students were failed to give a single example for the therapeutic application on this aspect. Only 4\% were given at least one example on this section and almost all $96 \%$ doesn't know about its therapeutic application. When this study was considered all the section, this section can be ranked as the poorest outcome among all three sections (Table 3). Further questioning revealed that the student's RNAi therapeutic application given answer and when ask the question it also failed in this section. The result of this mechanism is consideration that RNAi will have a wide range of medical applications. It may be possible to use micro RNAs to stop function of an oncogenes. WOF is caused by oncogenes?And the outcome was $63.8 \%$ only, gave us a little satisfactory.

It is not clear that this why can transgenes activate RNAi, no doubt it gives $11.3 \%$, and manipulation far will result in $2^{\text {nd }}$ Year $(5 \%) ; 1^{\text {st }}$ Year $(5 \%) ; 4^{\text {th }}$ Year $1.3 \%$ and $3^{\text {rd }}$ Year $0 \%$, where $3^{\text {rd }}$ year students were unable to answer for this section. The possible "solution" to this difficulty is hinted at in the last part of the excerpt, and when the interviewer explicitly asked how this RNAi could account for the therapeutic application shown in Table 3 and explained. Data from the questionaire assessment were used to infer students' RNAi application methods. Relationships between latent variables such as given muscle disease and RNAi application obtained $23.8 \%$, and $33.8 \%$ respectively. In this study, the latent variables which explained about had a small low outcome but there was a relationship among them. Linkages between these ideas comprise an integrated understanding of RNAi application is poorly known by the medical faculty students at University or Rajarata, need to improve with any cost by modifying the current teaching methodology.

Table 2. Student responses in the RNAi section

\begin{tabular}{|l|l|l|}
\hline Question (Science concept) & Possible responses & $\begin{array}{l}\% \text { of } \\
\text { students } \\
\text { giving } \\
\text { response } \\
\text { (n=80) }\end{array}$ \\
\hline $\begin{array}{l}\text { Ribose Nucleic Acid } \\
\text { interference stands for } \\
\text { WOF? }\end{array}$ & RNA interference & 52.5 \\
\hline $\begin{array}{l}\text { Noble Price was won by } \\
\text { Andrew Fire and Craig } \\
\text { Mello in 2006 for their work, } \\
\text { begun in the late 1990s, on } \\
\text { RNAi. WOF organisms did } \\
\text { they work on? }\end{array}$ & Round worms & 16.3 \\
\hline $\begin{array}{l}\text { The short double stranded } \\
\text { RNA which effectors of } \\
\text { gene silencing molecules } \\
\text { produced by the action of the } \\
\text { enzyme dicer. } \\
\text { Approximately what is the } \\
\text { size of the molecules? }\end{array}$ & 22 bp & 10.0 \\
\hline
\end{tabular}


Table 3. Student responses in the RNAi application

\begin{tabular}{|l|l|l|}
\hline Question (Science concept) & Possible responses & $\begin{array}{l}\% \text { of } \\
\text { students } \\
\text { giving } \\
\text { response } \\
\text { (n=80) }\end{array}$ \\
\hline $\begin{array}{l}\text { There are hopes that RNAi } \\
\text { will have a wide range of } \\
\text { therapeutic applications. It } \\
\text { may be possible to use } \\
\text { microRNAs to silence } \\
\text { oncogenes. Which of the } \\
\text { following is caused by } \\
\text { oncogenes? }\end{array}$ & Cancer & 63.8 \\
\hline $\begin{array}{l}\text { Why can transgenes activate } \\
\text { RNAi (can circle more than } \\
\text { one) }\end{array}$ & $\begin{array}{l}\text { Their insertion activates } \\
\text { the transcription of } \\
\text { miRNAs }\end{array}$ & 11.3 \\
\hline $\begin{array}{l}\text { Patients who have a disease } \\
\text { called X have over growth in } \\
\text { muscle. Scientists know that X } \\
\text { is inherited (caused by a } \\
\text { gene). Therefore, the gene } \\
\text { responsible for X does not } \\
\text { contain correct information } \\
\text { about: }\end{array}$ & $\begin{array}{l}\text { The composition of } \\
\text { muscle tissue }\end{array}$ & 23.8 \\
\hline $\begin{array}{l}\text { To cure the above symptoms } \\
\text { RNAi therapy can be } \\
\text { introduce, what is the main } \\
\text { function of it. }\end{array}$ & $\begin{array}{l}\text { RNAi silencing complex } \\
\text { to guide } \\
\text { mRNA cleavage, so } \\
\text { promoting } \\
\text { mRNA degradation and } \\
\text { reduce } \\
\text { over expression of } \\
\text { protein }\end{array}$ & 33.8 \\
\hline $\begin{array}{l}\text { Give an example of an RNAi } \\
\text { therapy which is used current } \\
\text { treatment to cure any disease/s }\end{array}$ & $\begin{array}{l}\text { Correct Answer } \\
\text { No Idea }\end{array}$ & \\
\hline
\end{tabular}

\section{DISCUSSION}

In this study with medical faculty students in Northeastern part of the Sri Lanka, it was observed that $96 \%$ of students gave wrong or no idea for RNAi based therapeutic applications. Curriculum developers need to interfere and must find out in which level genetics should be introduced into the intended learning outcomes by considering the above results. According to some foreign expertise in the field of education commenced specially Marbach-Ad and Stavy (9) that before 16 is the best for the genetic education (20). Furthermore some experts explained that this age which they found was difficulties in understanding genetics education at school (9). Studies done by Lewis et al (8) and Marbach-Ad and Stavy showed that the concepts in genetics teaching must align with "compartmentalized" and "without providing any conceptual frame work," which could be a disaster result of teaching methodology such as passive learning. In Sri Lankan education system molecular genetics taught at different levels often are not connected properly from ordinary level to advanced level, and the gap between the two remains high. Banet and Ayuso (21) commented, "From an academic point of view, we must consider it important to provide students with a basic conceptual framework for understanding the location, transmission and expression of hereditary information and the basic mechanisms involved in the evolution of living beings.
Such knowledge would also help students to understand the biological significance of certain phenomena such as cell division, the reproduction. Finally therapeutic application based on RNAi.,

Some studies and the work reported that it indicated the teaching of molecular genetics needs considerable review and strengthening before it comes in pipeline. Because the basic and abstract nature of genetics is itself difficult to conceptualize, therefore other teaching aids such as photographs, film and video, time-lapse phase contrast microscopy, models, etc. could be introduced to explain in a simple manner which the dynamic nature of the various processes, such as protein production from mRNA messenger in active learning manner. The importance must be emphasized in teaching and learning genetics should not be confined to covering the topics and having students memorize them by rote. Instead, genetics teaching should aim to instill conceptual understanding of the subject area and encourage thinking during the learning activities such as student oriented. Only then will students be able to assimilate and accommodate the related information in real-life situations.

\section{CONCLUSIONS}

In conclusion, the complex Ribose Nucleic Acid interference therapeutic application in this study prompted a more nuanced investigation of students' responses, yielding more insight into student learning about Ribose Nucleic Acid interference topics. These research findings have implications for the design of instruction, student-learning materials, assessments, and teacher support materials as well as the research conducted on science teaching and learning. Leveraging this work, future research studies should optimize the contributions of both quantitative analyses of student performance and more in-depth analysis of students' written responses in therapeutic application based on Ribose Nucleic Acid interference. Finally, future research studies can contribute to the field by providing more details about science learning and the supports necessary to help students develop a deep understanding about fundamental science topics that effect society with new technology and therapeutic application.

\section{REFERENCE}

[1] Davis, I.C., Science in functional living. 32, 1948(3): p. 136-137.

[2] Duncan, R.G., A.D. Rogat, and A. Yarden, A learning progression for deepening students' understandings of modern genetics. Journal of Research in Science Teaching, Journal of Research in Science Teaching,, 2009. 46(6): p. $655-674$.

[3] Chattopadhyay, A., Understanding of Genetic Information in Higher Secondary Students in Northeast India and the Implications for Genetics Education. Cell Biology Education, 2005. 4: p. 97-104.

[4] Hallden, O., The evolution of the species: pupil perspectives and school perspectives. International Journal of Science Education, 1988. 14: p. 541-552. 
[5] Longden, B., Genetics - are their inherent learning difficulties? Journal of Biological Education, 1982. 16: p. 135-140.

[6] Kindfield, A.C.H., Assessing understanding of biological processes: elucidating students' models of meiosis. The American Biology Teacher, 1994. 56: p. 367-371.

[7] Brumby, M.N., Misconceptions about the concept of natural selection by medical biology students. Science Education, 1984. 68: p. 493-503.

[8] Lewis, J., J. Leach, and C. Wood-Robinson, All in the genes?-Young people's understanding of the nature of genes. Biological Education, 2000. 34(2): p. 74-79.

[9] Marbach-Ad, G., Attempting to break the code in students' comprehension of genetic concepts. Journal of Biological Education, 2001. 35(4): p. 183-189.

[10] Wood-Robinson, C., J. Lewis, and J. Leach, Young people's understanding of the nature of genetic information in the cells of an organism. Journal of Biological Education, 2000. 35(1): p. 29-36.

[11] Tuschi, T., Expanding small RNA interference. Nature Biotechnology, 2002. 20: p. 446-447.

[12] Almeida, R. and R.C. Allshire, RNA silencing and genome regulation,. Trends Cell Biology, 2005. 15(251-258).

[13] Orcajo, T.I. and M.M. Aznar, Solving problems in genetics II: Conceptual restructuring. International Journal of Science Education,, 2005. 27(12): p. 1495 1519.

[14] Venville, G., S.J. Gribble, and J. Donovan, An exploration of young children's understandings of genetics concepts from ontological and epistemological perspectives. Science Education, 2005. 89: p. 614 - 633.

[15] Alozie, N., J. Eklund, A. Rogat, and J. Krajcik, Genetics in the 21st century: The benefits \& challenges of incorporating a project-based genetics unit in biology classrooms. The American Biology Teacher, 2010. 72(4): p. $225-230$.

[16] Duncan, R.G. and B.J. Reiser, Reasoning across ontologically distinct levels: Students' understandings of molecular genetics. Journal of Research in Science Teaching,, 2007. 44(7): p. 655-674.

[17] Lewis, J. and U. Kattmann, Traits, genes, particles and information: re-visiting students' understandings of genetics. International Journal of Science Education, 2004. 26(2): p. 195-206.

[18] Dawson, V. and R. Schibeci, Western Australian school students' understanding of biotechnology. International Journal of Science Education, 2003. 25: p. 57 - 69.

[19] Zohar, A. and F. Nemet, Fostering students' knowledge and argumentation skills through dilemmas in human genetics Journal of Research in Science Teaching, 2002. 39: p. $35-62$.

[20] Shayer, M., Conceptual demands in the Nuffield O-level biology course. Sch. Sci. Rev., 1974. 56: p. 381-388.

[21] Banet, E. and G.E. Ayuso, Teaching of biological inheritance and evolution of living beings in secondary school. International Journal of Science Education, 2003. 25(3): p. 373-407.

\section{Authors' Profiles}

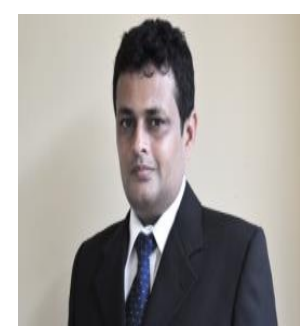

Faiz MMT Marikar is the most experienced scientist in the field of molecular biology, and he is currently working as the Director, Staff Development Centre, General Sir John Kotelawela Defence University Sri Lanka. He has B.Sc. Special Degree from University of Ruhuna. After he was graduated he went to University of Sheffield, United Kingdom for his post graduate degree and then he transferred it to University of Nanjing, PR of China. He has a M.Sc.; Ph.D. and D.Sc. from Nanjing University, PR of China. His Ph.D. thesis was merely based on genetics, molecular biology, and microbiology related to human cancer genetics. Furthermore, Dr. Faiz Marikar was offered a Fulbright Fellowship and trained his Post-Doctorate at University of Johns Hopkins, and he was received Occasional Lecture Fund to be work at University of Harvard in year 2009-2010, and he received Honorary Post Doctorate from University of Colombo after his arrival from USA.

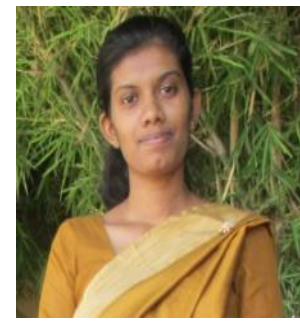

Manel BCN Kulugammana currently studying as a fourth year medical student at Faculty of medicine university of Rajarata, Saliyapura, Anuradhapura, Sri Lanka.

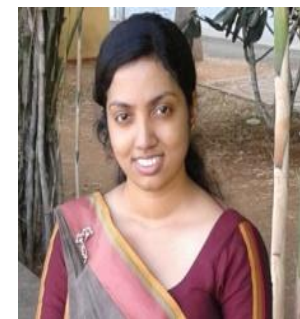

Karawitage RL Karawita currently studying as a fourth year medical student at Faculty of medicine university of Rajarata, Saliyapura, Anuradhapura, Sri Lanka.

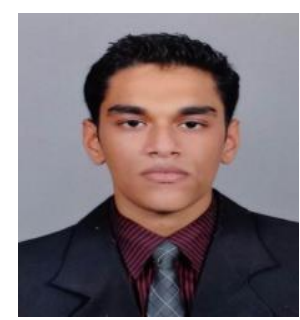

Aravinda S Jayathilake currently studying as a fourth year medical student at Faculty of medicine university of Rajarata, Saliyapura, Anuradhapura, Sri Lanka.

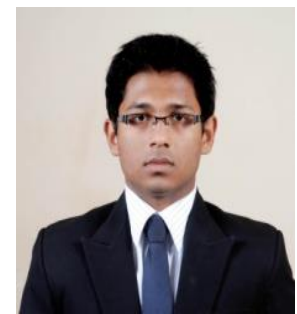

Ayesh U Hettiarachchi currently studying as a fourth year medical student at Faculty of medicine university of Rajarata, Saliyapura, Anuradhapura, Sri Lanka. 


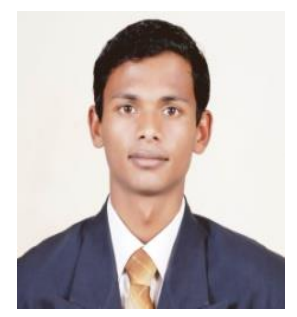

Kesaven Kalainesan currently studying as a fourth year medical student at Faculty of medicine university of Rajarata, Saliyapura, Anuradhapura, Sri Lanka.

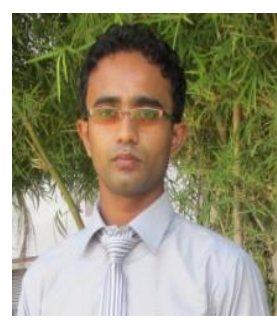

Eranda I Kumara currently studying as a fourth year medical student at Faculty of medicine university of Rajarata, Saliyapura, Anuradhapura, Sri Lanka.

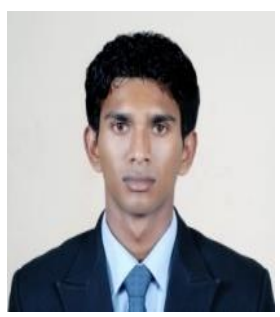

Kodithuwakkulage MP Kumara currently studying as a fourth year medical student at Faculty of medicine university of Rajarata, Saliyapura, Anuradhapura, Sri Lanka.

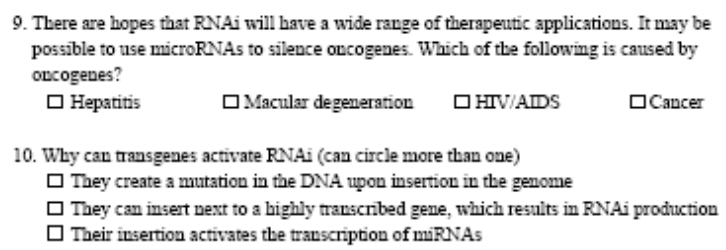

9. There are hopes that RNAi will have a wide range of therapeutic applications. It may be possible to use microRNAs to silence oncogenes. Waich of the following is caused by oucogenes?

$\square$ Hepatitis $\square$ Macular degeneration $\square$ HIV/ADS $\square$ Cancer

10. Why can transgenes activate RNAi (can circle more than one)

$\square$ They create a mutation in the DNA upon insertion in the genome

$\square$ They can insert next to a bighly transcribed gene, which results in RNAi production

$\square$ Their insertion activates the transcription of miRNAs

11. Patieats who have a disease called $\mathrm{X}$ bave over growth in muscle. Scientists hnow that $\mathrm{X}$ is inherited (caused by a gene). Therefore, the gene responsible for $\mathrm{X}$ does not contain correct information about:

$\square$ The proper fiuction of muscle cells

$\square$ The structure of a contracting protein in muscle cells

The amount of energy that should be allocated to muscle cells.

The composition of muscle tissue.

12. To cure the above symptoms RNAi therapy can be introduce, what is the main function of it $\square$ RNAi belp proteins canry out tieir functions.

$\square$ RNAi silencing complex to guide mRNA cleavage, so promoting mRNA degradation and reduce over expression of protein

$\square$ RNAi belp to form dicer and it will lead to block protein production

$\square$ There is no convection between RNAi and cure the disease.

13. Give an example of an RNAi therapy which is used current treatment to cure any disease/s
Questionnaire to assess student's lnowledge about RNAi technology

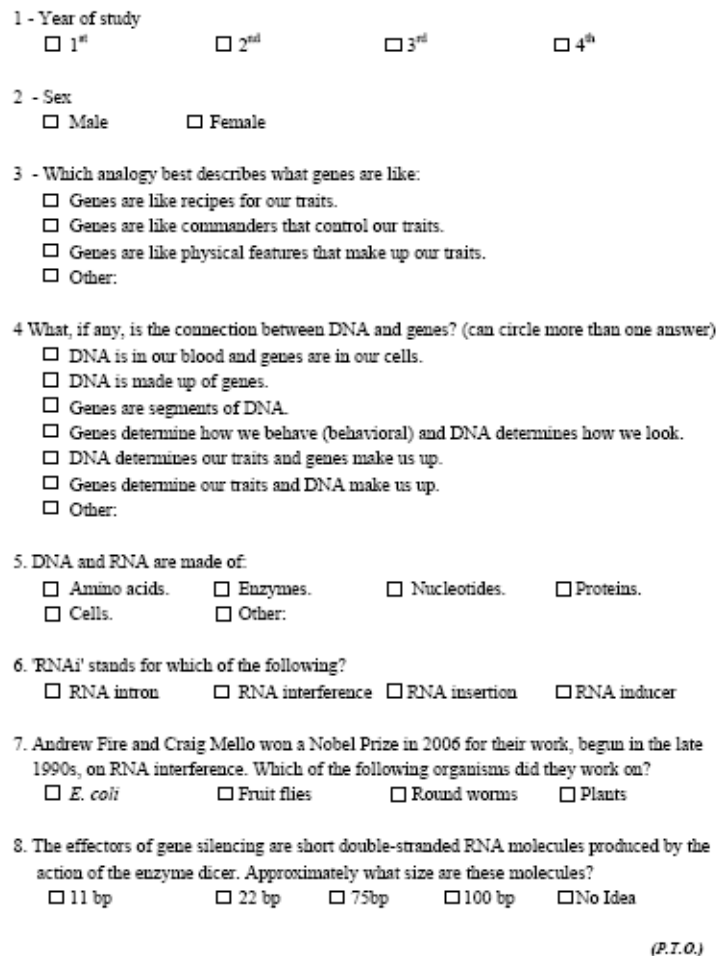

